\title{
Brincar / Play
}

https://doi.org/10.21814/uminho.ed.36.8

\section{Manuela Ferreira}

Faculdade de Psicologia e de Ciências da Educação, Universidade do Porto, Portugal 



\section{Brincar}

O brincar, na sua variabilidade e complexidade humana, é um conceito chave no campo da Sociologia da Infância. Ele é essencial para entender a infância como uma construção socio-histórica de tipo geracional nas sociedades ocidentais, para repensar as crianças como membros ativos da sociedade e produtoras de culturas de pares; para reconhecer a expressão das suas múltiplas e diferentes vozes enquanto modos particulares de participação social e num mundo mais que humano.

Com efeito, ao longo do século XX nas sociedades ocidentais, o brincar tornou-se predicado da natureza infantil e um dos fundamentos da alteridade das crianças em relação aos adultos e seus mundos; um espaço-tempo para se experimentarem a si, aos outros e ao mundo, adquirindo saberes estruturantes da sua formação pessoal, social e cultural, vindo a ganhar estatuto de direito próprio e universal (art. ${ }^{\circ} 31$, CDC, 1989). Nesta definição das definições da infância, e uma das descrições mais relevantes das suas ações sociais, enfatiza-se a pertinência e o valor da ludicidade inerente à participação ativa das crianças em atividades autodeterminadas, voluntárias e livremente escolhidas, autogratificantes, prazerosas e divertidas, imaginativas e triviais, fluidas e incertas, e autotélicas, sem objetivos extrínsecos e economicamente improdutivas.

No campo das Ciências Sociais, o brincar infantil tem sido frequentemente traduzido e valorizado como uma atividade promotora do desenvolvimento linguístico/cognitivo da criança, por parte da Psicologia do Desenvolvimento, e da aquisição de competências sociais necessárias ao desempenho de futuros papéis na sociedade e à sua integração social, por parte da Sociologia clássica. A tipificação de atividades do brincar e suas funções, associada a níveis de progressão do desenvolvimento individual das crianças, tendeu a sublinhar os comportamentos observáveis do que elas faziam, mas de um modo socialmente descontextualizado, anacrónico e adultocêntrico, e a instrumentalizar a sua funcionalidade aos processos de ensino-aprendizagem formais.

Estudos sociológicos da infância dedicados à compreensão das ações das crianças na sociedade também valorizam o brincar, focando os processos 
socioculturais nos quais os "como" brincar se entretecem e, nessas relações, são (re)produzidas rotinas da cultura de pares global/localmente recontextualizadas. Os modos específicos das crianças interpretarem, simbolizarem e agirem no mundo pela adoção, confronto e/ou contraponto à ordem adulta e/ou entre pares, são então reconhecidos como significativos para elas gerarem experiências e entendimentos comuns, portadores de sentidos partilhados para as suas próprias ações no seio da heterogeneidade de classe social, género, idade, etnia, religião, experiência institucional, etc. Tais modos de estar, fazer e sentir são usados como conhecimentos e competências sociais para as crianças participarem, tanto no mundo adulto e se afirmarem diferentemente perante ele, como no mundo das crianças e enquanto membros abalizados umas perante as outras.

$\mathrm{Na}$ atenção aos modos como as crianças criam entre si versões da realidade alternativas às dos adultos destacam-se as culturas lúdicas, particularmente o fazer como se ou faz-de-conta; essas interpretações não-literais que permitem às crianças dissociarem-se da realidade adulta que as inspira, da qual participam e fazem parte, assim produzindo um mundo de fantasia. Ou seja, de elaborarem um contexto de pretensão, temporário e limitado, como uma espécie de "bolha de perfeição num mundo imperfeito" que viabiliza agirem na fronteira entre fantasia e realidade. É essa não-literalidade que consente que o brincar seja brincar e que este possa ser entendido como um texto - em que as crianças contam as suas próprias histórias e versões da realidade, dizem de si e comentam as suas inúmeras relações - e, ao mesmo tempo, como um contexto em que aprendem que os comportamentos, as relações interpessoais de autoridade ou os afetos são por ele influenciados, num campo de negociações de significados expressos em múltiplas linguagens. 0 brincar, sendo parte integrante da vida social das crianças, longe de estar separado do mundo real constitui, portanto, um modo de estar nele e de agir sobre ele. Daí que, eventos socioculturais e lúdicos das crianças como o brincar constituam acessos privilegiados para compreender a interdependência entre relações e culturas adultas e infantis, suas sociabilidades, a organização social do grupo de pares e modos de participação; i.e., aquilo possibilita e constrange a sua agência e torna significativas as experiências de serem/tornarem criança entre crianças e com adultos.

Mais recentemente, novos entendimentos do brincar, perspetivando que as relações das crianças com o mundo que habitam estão situadas em contextos mais que sociais, sublinham o agenciamento da materialidade, seja ela natureza, corpos, tecnologias, artefactos ou arquiteturas, nos seus 
contínuos encontros. 0 desafio é exceder as dicotomias tradicionais (corpo/ mente, natureza/cultura, indivíduo/social, sujeito/objeto, discurso/matéria, etc.) para recolocar e reconhecer a coexistência e amálgama humana com o resto do mundo e todos os tipos de coisas, espécies não humanas e matéria (manufaturada e orgânica, viva e inerte, entidades e forças), resgatando-os da invisibilidade, inação e passividade. Realçar a ação do lugar, objetos e matéria no brincar das crianças, retirando-os de um papel subsidiário, requer tomá-los como causas e repercussões instigadoras, intrigantes e interpelativas que, ao também "brincarem" com elas enquanto "tentam tornar-se inteligíveis uns aos outros" (Lenz Taguchi, 2010, p. 152), entram num jogo de mútua afetação, agenciamento, produção e transformação. Olhar esta íntima relação no inextricável emaranhamento entre humanos e 0 mais que humano que acontece nos encontros lúdicos do brincar incita, então, a entendimentos mais complexos e dinâmicos acerca da multitude de agências constantemente presentes, mas frequentemente ignoradas ou tomadas como certas.

\section{Play}

Play, in its enormous human variability and complexity, is a key concept in the field of Sociology of Childhood. It is essential, both for understanding childhood as a generational socio-historical construction in Western societies, as well as for reconceptualising children as active members of society and producers of peer cultures. It is also important for the political recognition of the expression of children's multiple and different voices as particular forms of social participation and in the more than human world.

Indeed, throughout the 20th century in Western societies, playing has become the predicate of children's nature and one of the foundations of their otherness in relation to adults and their worlds; a space-time for them to experience themselves, others, and the world, acquiring the structuring knowledge of their personal, social, and cultural development. Indeed, play has gained status as a universal right (art. 31, UNCRC, 1989). In this definition of childhood, one of the most relevant descriptions of children's social actions, the emphasis is placed on the playfulness inherent in the active participation of children in self-determined, voluntary, and freely chosen activities that are self-gratifying, pleasant, fun, and imaginative, trivial, fluid, uncertain, and autotelic, economically unproductive and without extrinsic goals. 
In the field of Social Sciences, children's play has often been translated and valued as an activity that promotes the child's linguistic/cognitive development, on the part of Developmental Psychology, and the acquisition of social skills necessary to perform future roles in society and to social integration, advocated by classical sociology. The typification of playing activities and their functions, associated with levels of progression in children's individual development, tended to highlight their observable behaviours, but in a socially decontextualized, anachronistic, and adult-centric way, and to instrumentalize its functionality for formal teaching-learning processes.

Childhood sociological studies dedicated to understanding children's actions in society also value play, focusing on the socio-cultural processes in which the "how" to play is integrated and, in these relationships, global/locally recontextualized culture routines are (re)produced. The specific ways in which children interpret, symbolize and act in the world through adoption, confrontation and/or counterpoint to the adult order and/or among peers, are then recognized as significant for them to generate common experiences and understandings, carriers of shared meanings for their own actions within the heterogeneity of social class, gender, age, ethnicity, religion, institutional experience, etc. Such ways of being, doing and feeling are used as social knowledge and competence for children to participate, not only in the adult world where they assert themselves differently, but also in the world of children, as competent members in relation to one another.

When paying attention to the ways in which children create alternate versions of reality among themselves, playful cultures stand out, particularly the "doing as if" or "make-believe"; these non-literal interpretations allow children to dissociate themselves from the adult reality that inspires them, in which they participate and are part of, thus producing a world of fantasy. In other words, children are able to create a context of pretense, temporary and limited, as a kind of "bubble of perfection in an imperfect world" that makes it possible to act on the line between fantasy and reality. It is this non-literality that allows play to be play; it can be understood as a text - in which children tell their own stories and versions of reality, speak about themselves and comment on their innumerable relationships - and at the same time, as a context in which they learn that behaviours, interpersonal relations of authority or feelings are influenced by it, in a field of negotiations of meanings expressed in multiple languages. Playing, as an integral part of children's social life, is far from being separated from the real world, and so, is a way of being in it and acting on it. Hence, children's socio-cultural and ludic events such as play constitute a privileged 
access to understanding the interdependence between adult and children's relationships and cultures, their sociability, the social organization of the peer group and their own forms of participation, i.e., what enables and constrains their agency and makes the experiences of being/becoming a child among children and adults significant.

More recently, new perspectives on play, which consider that children's relations with the world develop in contexts other than social, underline the influence of materiality, be it nature, bodies, technologies, artefacts, or architectures, in their continuous encounters. The challenge is to overcome traditional dichotomies (body/mind, nature/culture, individual/social, subject/object, discourse/matter, etc.) to relocate and recognize human coexistence and mixing with the rest of the world and all types of things, non-human species, and matter (manufactured and organic, living and inert, entities and forces), rescuing them from invisibility, inaction, and passivity.

Enhancing the role of place, objects, and matter in children's play and removing their subsidiary status, require viewing them as influential and intriguing causes and repercussions; while "playing" with them, they are "trying to become intelligible to each other" (Lenz Taguchi, 2010, p. 152), participating in a game of mutual affectation, agency, production and transformation. Acknowledging this intimate relationship in the inextricable entanglement between humans and the more than human that happens in the encounters of play, leads to a more complex and dynamic understanding of the multitude of agencies that are constantly present, but often ignored or taken for granted.

\section{Referências / References}

Ferreira, M. (2004). A gente gosta é de brincar com os outros meninos!". Relações sociais entre crianças num jardim de infância. Porto: Edições Afrontamento.

Hackett, A., Procter, L. \& Seymour, J. (Eds.). 2015, Children's Spatialities. Embodiment, Emotion and Agency. Basingstoke, Hampshire: Palgrave Macmillan

Lenz Taguchi, H. (2010). Going Beyond the Theory/Practice Divide in Early Childhood Education: Introducing an Intra-active Pedagogy. London: Routledge. 